\title{
Investigation of Power Supply to Subsea Loads from High Voltage Electric Source Using Modular Direct Current Scheme
}

\author{
Biweri Kainga1, Roupa Agbadede ${ }^{2}$ \\ ${ }^{1}$ Department of Mechanical Engineering, Nigeria Maritime University, Warri, Nigeria \\ ${ }^{2}$ Department of Electrical Engineering, Nigeria Maritime University, Warri, Nigeria \\ Email: biweri.kainga@nmu.edu.ng
}

How to cite this paper: Kainga, B. and Agbadede, R. (2020) Investigation of Power Supply to Subsea Loads from High Voltage Electric Source Using Modular Direct Current Scheme. Journal of Power and Energy Engineering, 8, 22-34.

https://doi.org/10.4236/jpee.2020.86003

Received: April 19, 2020

Accepted: June 25, 2020

Published: June 28, 2020

Copyright $\odot 2020$ by author(s) and Scientific Research Publishing Inc. This work is licensed under the Creative Commons Attribution International License (CC BY 4.0).

http://creativecommons.org/licenses/by/4.0/

\begin{abstract}
Subsea power converters have been identified in recent researches as a potential means of supplying power to subsea loads and this technology has been seen as a means to reduce the reliance on offshore platforms. This study analyses all electric subsea high power system for power generation and transmission in the offshore oil and gas industry for sustainable subsea development. In order to accomplish the analysis of power generation and transmission to subsea loads, the MAT lab SIMULINK software was employed to ascertain losses arising from the transmission of power to subsea systems. Data from Agbara and Akpo fields, all located in Nigeria, were analysed using the MSDC model as an alternative power source for power generation and transmission to all subsea loads. When the voltage loss between a step out distance at $30 \mathrm{~km}$ and $200 \mathrm{~km}$ was compared for the Akpo oil field, the plots indicate a significant loss in voltage. The RMS value of voltage loss increased from 0.8874 at a step out distance $30 \mathrm{~km}$ to 0.9449 for $200 \mathrm{~km}$.
\end{abstract}

\section{Keywords}

Subsea Loads, Risk Analysis, Voltage Loss, Power Systems

\section{Introduction}

The demand for energy is growing all over the world due to industrialization, economic development and population growth. The United States Energy Information Administration (USEIA) predicts that the demand of energy will increase continuously from 2010 to 2040 [1]. The offshore oil and gas production is moving towards the exploration of unconventional oil at a water depth of 
above $3000 \mathrm{~m}$ (Ultra Deep-water) located hundreds of miles away from the shore, where subsea process is usually preferred for technical and economic reasons. Subsea power converters have been identified in recent researches for the supply of power to subsea loads and this technology has been seen as a means to reduce the reliance on offshore platforms.

The overall power requirement can range from tens of kilowatt $(\mathrm{kW})$ to megawatt (MW), so the need for reliable power transmission and distribution system to power the subsea equipment becomes imperative. Power generation for subsea loads could be generated by wind turbine, solar systems, gas turbine on offshore platforms, and connecting from national grid to supply subsea loads. This research is focused on powering subsea loads from High Voltage Electric power source using modular Subsea Direct current system. Also, the study intends to highlight the potential benefits of adopting the proposed method of generating and transmitting power to subsea loads.

One of the major problems in analyzing subsea systems is based on the fact that every project is designed with its own specific subsea component and facilities. This is a challenge in the industry, because equipment is qualified on a per project basis rather than having a common standard [2]. The JIP (Joint Industry Project) on subsea electric power standardization published an international industry standard on the design, testing and qualification of subsea power transformers. This was done to reduce the cost for subsea field development by creating more uniformity in the industry [3]. Gas turbines on offshore platforms have increased the emission of $\mathrm{CO}_{2}$ and $\mathrm{NOx}$, to the environment and this has contributed negatively on climate change. Therefore, the need for a cleaner energy option becomes imperative.

Jorun et al. [4] focused on wind turbine as the alternative power source for offshore platforms to be used in the Norwegian region. It was stated that high voltage alternating current (HVAC) cable was suggested to be used for transmission of power from shore to offshore, while high voltage direct current for power transmission over long distances. In addition, the authors performed a steady state power flow analysis to assess power loses and voltage drops throughout the system for the different scenarios. The results show that there were more losses on the $280 \mathrm{~km}$ cables when compared to the supply from the wind turbine which is located closer to the petroleum platforms. The generation and transmission of power to subsea loads from onshore power systems has been identified as another option for subsea field development. However, this task is very challenging not only because the equipment used is submerged in sea water at depth around 3000 meters, but other important aspects are its accessibility for repair or replacement of component due to faults or regular maintenance. The transmission of power from onshore has advantages such as high availability (approximately 99\%), increased life span (Approximately 30 years) and increased efficiency in fuel to electric power energy conversion. Also, the scheme requires less maintenance and shorter repair or downtime [5]. 
The available literature on high power system for subsea development only proffers information and systems of various orientations without a proper power transmission module to the subsea loads. Also, most of the available studies are focused on the Norwegian continental shelf due to their stiff regulations to reduce emission of hazardous gases to the environment. An all-electric subsea process has been analysed but there is no wide application in the world. Analysis available like the module for the BP forties platform did not consider the supply of generated power to subsea loads [6]. Hence, knowledge gap in an all-electric subsea system, subsea power supply via transmission cables is very limited as this technology is new to the oil and gas industry. With recent technology available in the oil and gas industry and also recent HVDC cables, in addition with proper analysis, a suitable system can be analysed to meet the present day requirements.

\section{Methodology}

Data from Agbara and Akpo fields, all located in Nigeria were analysed using the MSDC model as an alternative power source for power generation and transmission to all subsea loads. Agbara Field

\section{Agbara Field}

Agbara field is operated by Agip Energy and Natural Resources (AENR) under a service contract with the Nigerian National Petroleum Corporation (NNPC). The field is located approximately $30-40 \mathrm{Km}$ from the shores of the Niger Delta offshore in water depth ranging between $55-70 \mathrm{~m}$. It is located in the offshore depo-belt of the Niger delta basin where thick pliocene-clastic sequences of Agbada formation have been deposited in a deltaic-fluvio-marine to inner shelf environment. Agbara field has been producing since June 1989 and its oil block, OPL 472, was converted into the Oil Mining Lease 116 (OML116) in September 1999. As at December 2009, the cumulative production is approaching $100 \mathrm{MMBBL}$ with an average production of about 10,000 barrels of oil per day (BOPD). With over twenty years of production, the Agbara case history presented in this research work constitutes a unique example of rejuvenation or enhancing production for a mature oil field [7]. The field consists of a wellhead platform, tied back to a processing platform. The produced oil is sent to ENI's Brass oil terminal, from where it is exported. The production capacity is about 10,000 BOPD.

\section{Akpo Field}

Akpo Floating Production storage and Offloading Vessel (FPSO) was commissioned in mid-2005 by total Nigeria upstream. The oil and gas field is located $200 \mathrm{~km}$ south of Port Harcourt, off the coast of Niger Delta in West Africa. The FPSO is moored in $1325 \mathrm{~m}$ depth of water situated at OML 130. Its vessel is $310 \mathrm{~m}$ long $61 \mathrm{~m}$ wide and has the capacity of $240 \mathrm{crew}$ members. It has a storage capacity of two million barrels of oil and the deck was designed to accommodate 17 topsides modules, which include two processing trains for 
the Separation of oil and water. The field is expected to produce 225,000 barrels of oil equivalent per day. The gas produced is pipelined to the Amenam AMP2 Platform $150 \mathrm{~km}$ away and then to the Bonny Island liquefied natural gas facility. Electrical power required to operate the subsea components of the field is about $100 \mathrm{MW}$, which is produced by six generator sets. The subsea setup of the field include 22 oil and gas production wells, 20 water injection wells and two gas injection wells [8].

\section{Simulations of Modular Subsea Direct Current System}

As mention earlier, data from Agbara and Akpo fields were implanted in the model and subsequently simulated, to ascertain the feasibility of the model. In addition, losses resulting from the power transmission to the subsea loads were investigated. Also, it was assumed that the cable under investigation was the cross-linked poly-ethylene (XLPE) High voltage DC cable. This was done to ascertain if the model proposed is feasible. The modular subsea direct current system shown in Figure 1 was obtained from literature, and was adopted in this study, to analyse the transmission losses for high power system. As reported in [1], the Model adopted in this study was developed using PSCARD. However, to achieve the objectives of the research, the system was re-modelled using MATLAB SIMULINK. Figure 1 shows the flow chart of the modular subsea direct current concept. The model Comprised four major blocks, namely the rectifier, DC transmission cable, inverter and Subsea loads (end Users).

The function of the Rect is to transform the alternating current generated from the power source to a Direct current; while the Dc transmission cable is used to transmit the power to the receiving end. The conversion of the Direct current from the transmission cable back to the alternation current is achieved using the Inverter. Finally, the last element in the block which is subsea loads consumes the current generated.

To simulate the power transmission from the source to the subsea load for the Agbara field, a 400KV XLPE cable was adopted. The cable parameters are

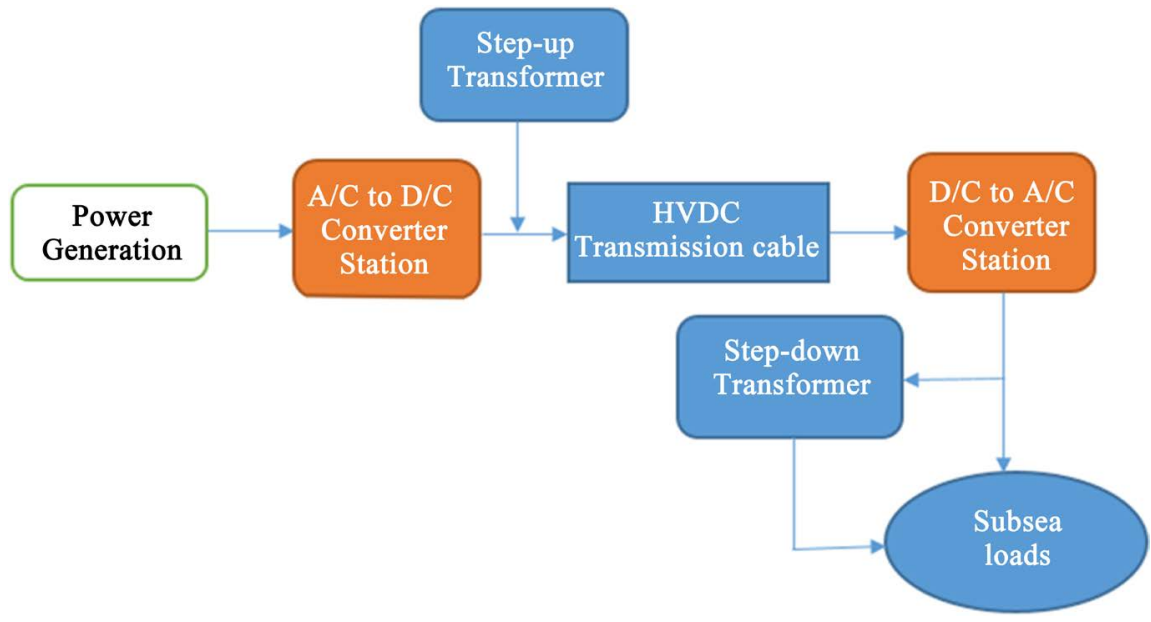

Figure 1. Modular subsea direct current system. 
presented in Table 1.

\section{Agbara field results for DC transmission under no load condition}

Using the data in Table 1 for the Agbara field, over a $30 \mathrm{~km}$ stepout distance was simulated with the assumption that the generated power is from shore. The following results were obtained for Direct current Transmission using the 400 KV XLPE cable under no load Condition. Under no load condition, the following values were obtained from the model after introducing the required power of 5 MW (see Table 2).

\section{Results and Discussion}

To investigate the influence step out distance on voltage losses, data obtained from two different locations namely Akpo and Agbara oil fields were simulated using MATLAB SIMULINK. The simulations were done at varying step out distances, ranging from $1-30 \mathrm{~km}$ and $1-200 \mathrm{~km}$ for the Agbara and Akpo oil fields respectively under no-load and load conditions. Figure 2 and Figure 3 show the source and sending voltage signals to rectifier block on the Simulink interface for without-load and load respectively. As can be seen visually, when screen shots are compared, the signal spikes for the load condition is larger and of greater density than the case without load. This simply indicates higher voltage loss for the load condition than the case without load.

Consequent upon modelling and conducting the simulation runs, the results were imported from the MATLAB platform to a Microsoft excel file, and consequently the results were plotted. Figure 4 shows the plots of voltage drop against

Table 1. Selected Cable Data Parameters for Modelling Agbara field.

\begin{tabular}{cc}
\hline Selected Cable Parameter & value \\
Cable Type & $400 \mathrm{kV}$ XLPE Cable \\
Cross Sectional Area & $1000 \mathrm{~mm}^{2}$ \\
Frequency & $50 \mathrm{H}_{\mathrm{z}}$ \\
Resistance per km & $0.0176 \mathrm{ohms} / \mathrm{km}$ \\
Capacitance per km & $4.01 \mathrm{e}^{-0.7} \mathrm{~F} / \mathrm{km}$ \\
Max. Temperature & 20 degrees Celsius \\
Nominal Current & $900 \mathrm{~A}$ \\
Power Required in Field & $5 \mathrm{MW}$
\end{tabular}

Table 2. Voltages passing through model at various stages under no load condition.

\begin{tabular}{cc}
\hline Selected Cable Parameter & Value \\
\hline Voltage passing through the DC transmission cable $(\mathrm{rms})$ & $2128 \mathrm{~V}$ \\
Voltage entering rectifier station $(\mathrm{rms})$ & $7449 \mathrm{~V}$ \\
Voltage entering at the receiving end (rms) & $7445 \mathrm{~V}$ \\
\hline
\end{tabular}




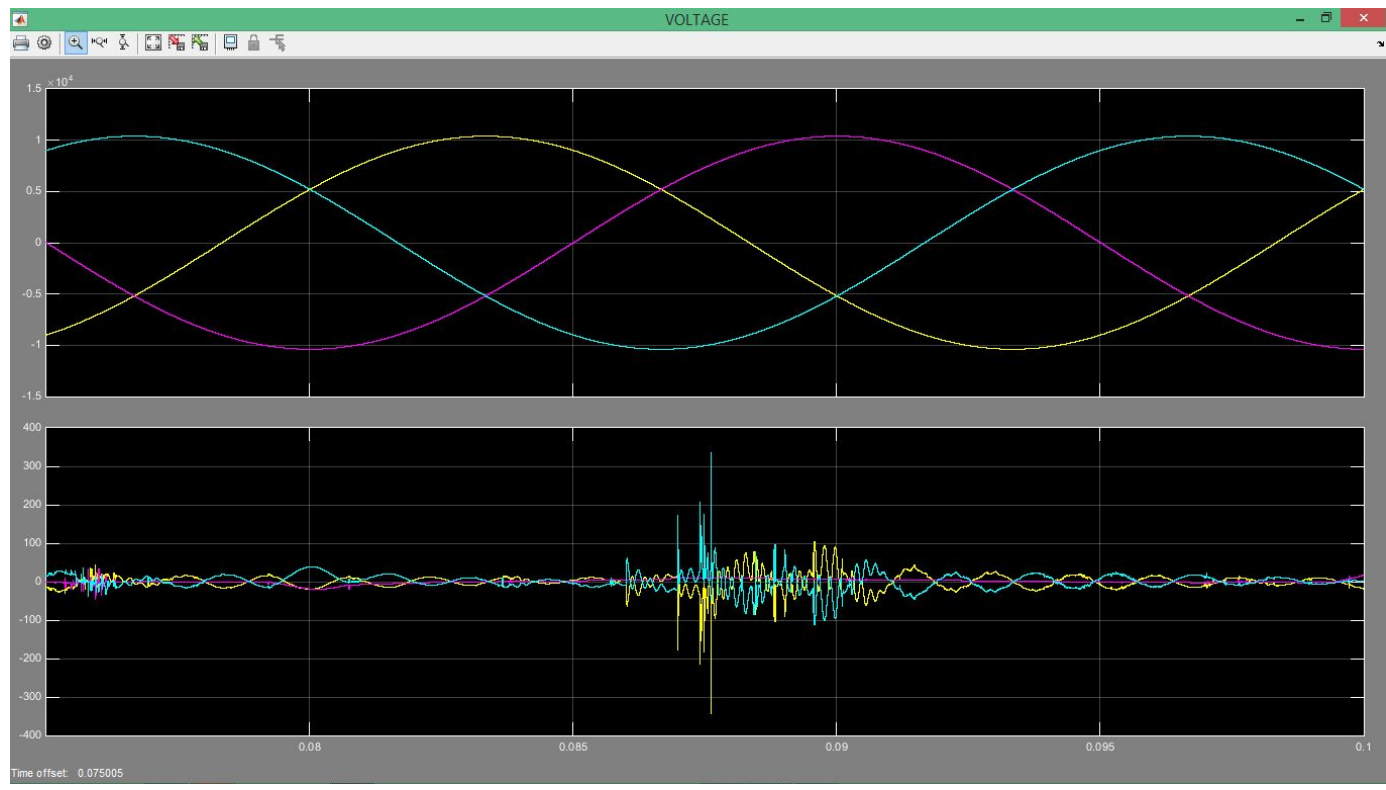

Figure 2. Source voltage and sending voltage to the Rectifier without load and load conditions.

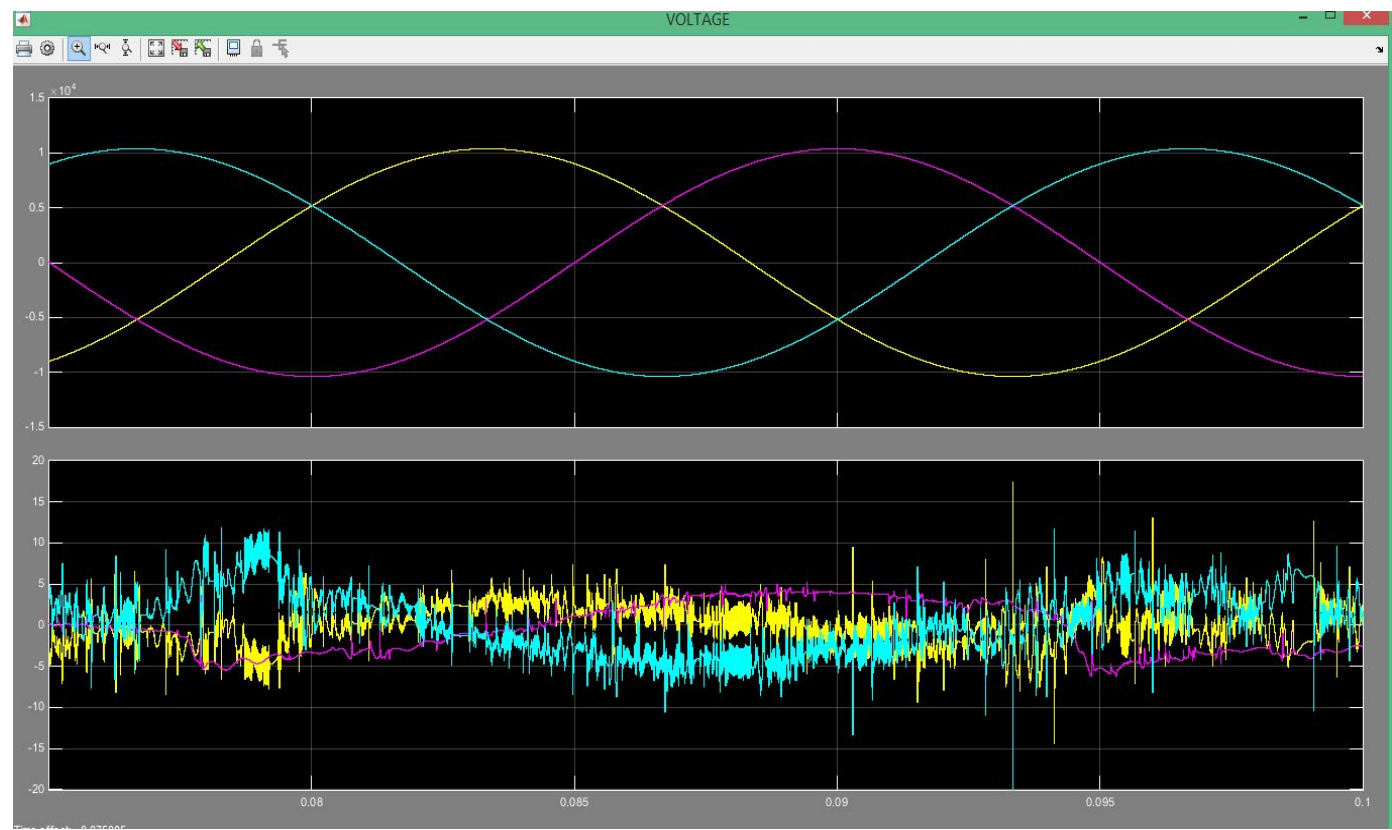

Figure 3. Source voltage and sending voltage to the Rectifier load conditions.

the step out distance for No-load and Load conditions. From the figure, it is obvious that voltage loss increased with step out distance for both No-load and Load conditions. Also, as can be seen from Figure 4, when the voltage loss between a step out distance $1-40 \mathrm{~km}$ and $1-200 \mathrm{~km}$ where compared for the Akpo oil field. The plots indicate a significant loss in voltage between a step out distance $1-40 \mathrm{~km}$ and $1-200 \mathrm{~km}$. The RMS value of voltage loss increased from 0.8728 to 0.8874 for a step out distance at 1 and $40 \mathrm{~km}$ respectively. This value of voltage loss from 1 to $40 \mathrm{~km}$ is about 1.65 percent. When the step out distance was increased from $1 \mathrm{~km}$ to $200 \mathrm{~km}$, the RMS value of voltage loss increased 
from 0.8728 to 0.9449 , which is approximately 7.6 percent loss in voltage. This can be attributed to losses associated with resistance. According to Ohm's law, the resistance of a conductor varies directly with length. Hence, for a longer distance, the voltage loss is expected to be higher. Another important point that was highlighted in the plots is the influence load. When the no load and loaded conditions compared, the voltage drop for the loaded condition is higher than the case without loading.

The bar chart plot of Figure 5 shows the percentage drop in voltage across the length of the cable. As depicted in the plots, the various stepout distances across the length of the cable were investigated to ascertain the voltage drops across the length of the cable. A step out distance covering a length of $200 \mathrm{~km}$ was investigated, in an increasing order $40 \mathrm{~km}$. As can be seen from Figure 5, it is obvious that the percentage drop in voltage from $1-40 \mathrm{~km}$ is significantly higher than from 160 - $200 \mathrm{~km}$.

Similar to the plots of Akpo Oil field, the Agbara oil field simulation results follow a similar pattern. Figure 6 shows that the voltage drop increased with distance for both no load and load conditions. In addition, the percentage drop

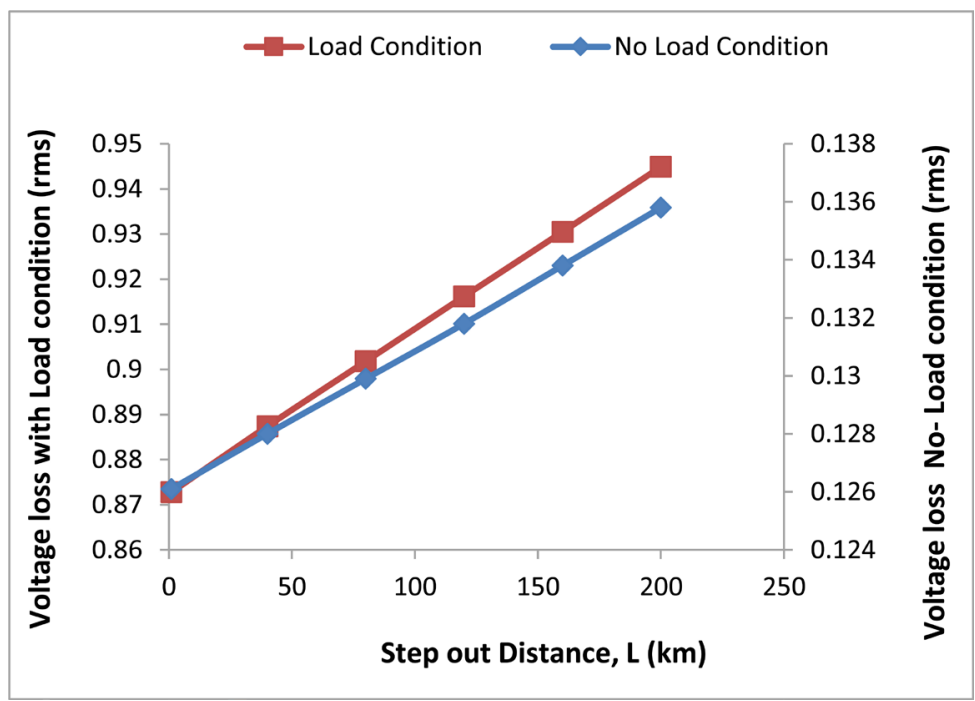

Figure 4. Voltage loss plots for no and load condition-Akpo 100MW Oil Field.

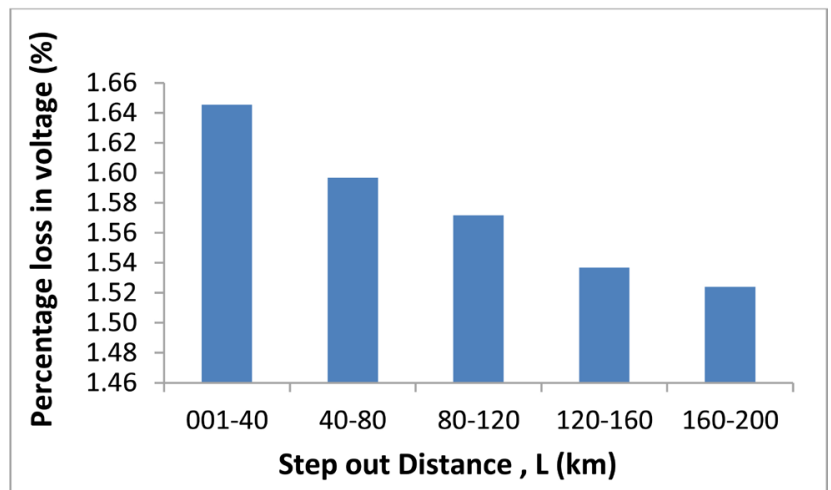

Figure 5. Percentage loss in voltage drop against length of cable for Akpo oil Field. 


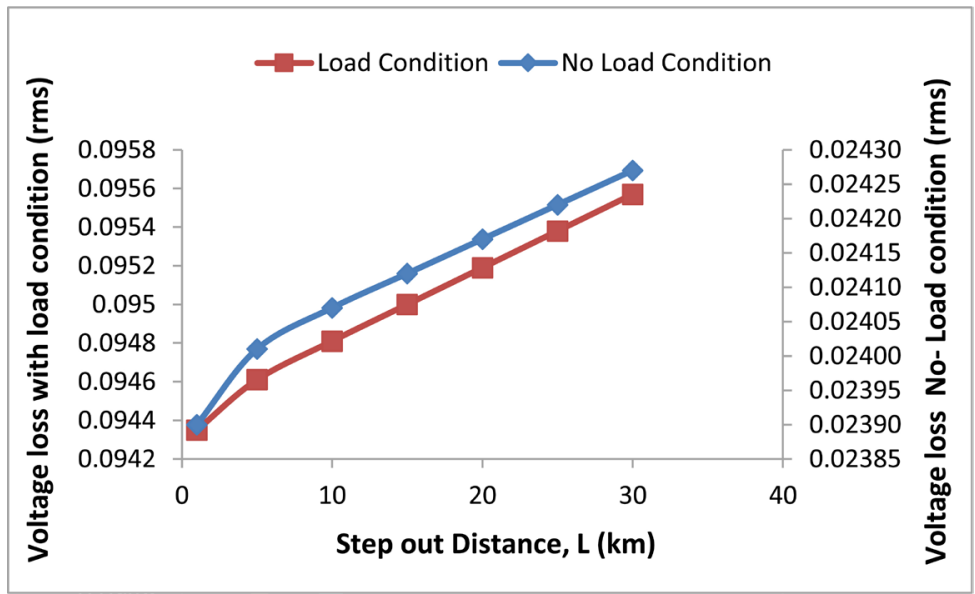

Figure 6. Voltage loss plots for no and load condition-Agbara 5MW Oil Field.

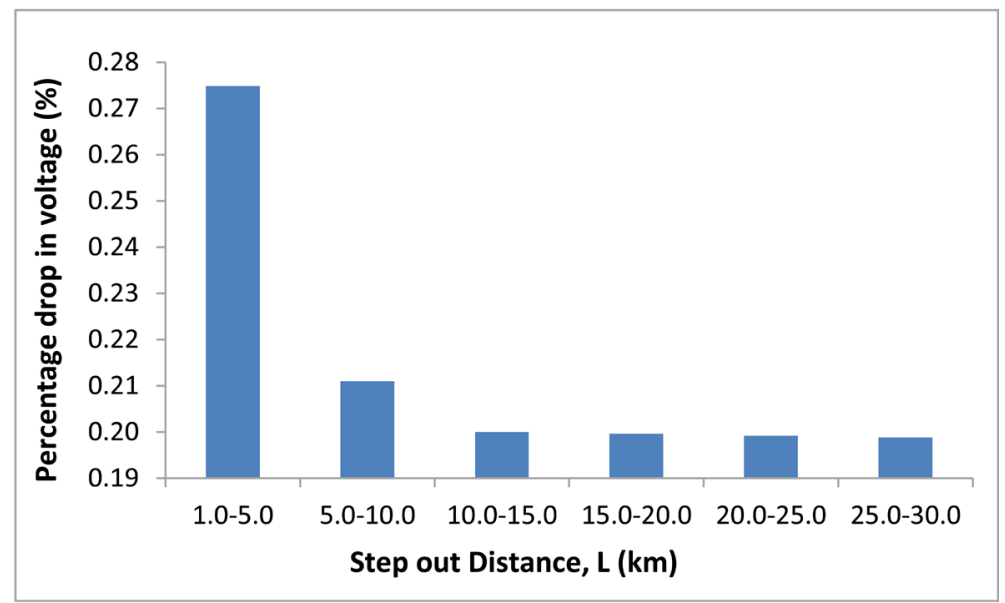

Figure 7. Percentage loss in voltage drop against length of cable for Agbara oil Field.

in voltage plots is similar to the ones of the Akpo Oil Field (see Figure 7). From results presented so far, the study demonstrates the feasibility of adopting high power systems to power subsea loads. This was proven and validated by the fact that the model run successfully and all the values of voltage losses fall within the range as provided in National Electrical code: 210-19(a), (FPN 4) and 215-2(b) which recommends a 5 percent voltage drop for feeder circuit.

The percentage loss in voltage for the oil fields: Akpo and Agbara were compared. It is worthy to note that the Akpo and Agbara oil fields have rated capacity of $100 \mathrm{MW}$ and $5 \mathrm{MW}$ respectively. The simulated results for Akpo oil field covered a step out distance from $1 \mathrm{~km}$ to $200 \mathrm{~km}$, while that of Agbara oil field considered only a step out distance from $1-30 \mathrm{~km}$. To compare the voltage loss for the two fields, it was only a step out distance from $1-30 \mathrm{~km}$ that was considered for both cases since the step out distance covered for Agbara oil field was only from $1-30 \mathrm{~km}$. As can be seen in Figure 8, the percentage loss in voltage for Akpo oil field is lower than the Agbara oil field. The percentage loss in voltage for Akpo field is $1.24 \%$ as against 1.27 for the Agbara field. This can attributed to the higher rating capacity for Akpo, which seems to minimize the effect 
on the voltage loss.

\section{Reliability Analysis}

No risk is negligible when designing systems for high reliability. The primary aim is for available systems to always perform its required function without any failure, so as to avoid down time. Therefore, taking these risk items into consideration during design of any subsea electrical system will help increase the time to failure and hence improve the reliability of the system. To establish the propose project in Nigeria, the authors are aware of other types of risks such as regulatory risk, political risk and financial risk. But other types of risks were not considered in this research work. Table 3 shows the parameters that were considered of risk and the outlined mitigation plans.

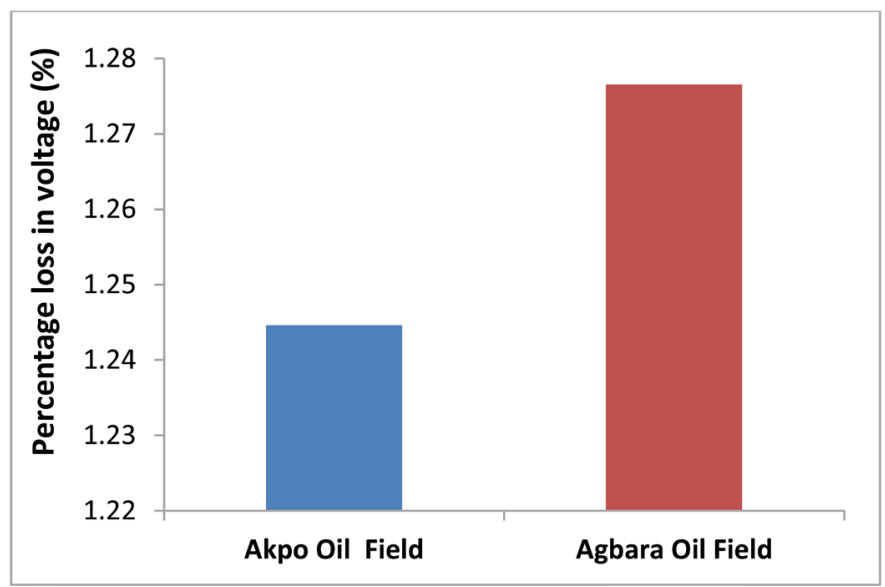

Figure 8. Percentage loss in voltage drop against length of cable for Akpo and Agbara oil Field.

Table 3. Risk assessment and mitigation plan.

\begin{tabular}{|c|c|c|c|c|}
\hline S/N & $\begin{array}{l}\text { Identified Risk } \\
\text { Item }\end{array}$ & Consequences & Possible Causes & Mitigation plan \\
\hline 1 & $\begin{array}{l}\text { Insulation } \\
\text { breakdown in } \\
\text { electrical } \\
\text { equipment and } \\
\text { cables }\end{array}$ & $\begin{array}{l}\text { Variation in } \\
\text { capacitance and } \\
\text { resistance between } \\
\text { wires }\end{array}$ & $\begin{array}{l}\text { Environmental Problems: } \\
\text { Contamination Moisture } \\
\text { and electric field } \\
\text { expansion, Arc tracking, } \\
\text { thermal aging, overload }\end{array}$ & $\begin{array}{l}\text { Periodic check on installation } \\
\text { will help reduce the risk of } \\
\text { occurrence }\end{array}$ \\
\hline 2 & $\begin{array}{l}\text { Harmonic } \\
\text { distortion }\end{array}$ & $\begin{array}{l}\text { Breakdown of } \\
\text { inverter or rectifier }\end{array}$ & $\begin{array}{l}\text { Overheating in } \\
\text { conductor, transformer or } \\
\text { induction motors. } \\
\text { Possible failure of power } \\
\text { correction capacitor }\end{array}$ & $\begin{array}{l}\text { Neutral conductor size can be } \\
\text { increased. The use of } \\
\text { harmonic filters }\end{array}$ \\
\hline 3 & Power Surge & $\begin{array}{l}\text { Equipment } \\
\text { damage }\end{array}$ & $\begin{array}{l}\text { Lightening, Overvoltage } \\
\text { (e.g. due to reduction in } \\
\text { subsea loads) }\end{array}$ & $\begin{array}{l}\text { A surge arrester or protector } \\
\text { with an indicator light is } \\
\text { highly recommended. Use of } \\
\text { voltage regulator in } \\
\text { equipment. Uninterrupted } \\
\text { power supply will prevent } \\
\text { surge }\end{array}$ \\
\hline
\end{tabular}


The fault tree diagram for the system configuration is shown below.

From the fault tree diagram in relation to the system configuration diagram (see Figure 9). The parameters: R1, R2, R3 and R4 represent the rectifier modules or blocks on the MSDC system configuration. While V1, V2, V3 and V4 represent the DC to AC (inverter) converter block. From the system configuration which consist of multiple small converter modules instead of one bulky centralized converter, makes it an attractive option for subsea application. The power architecture of the system is a new development in the subsea industry because all the loads are connected in series equivalently [1]. When a system or its components are connected in series, a failure of one component will lead to the failure of the entire system. But in this case, the provision of a bypass switch to isolate a faulty path or module of the system in case of any fault is adopted. Hence if there are faults in other parts of the system it will function without interruption due to the presence of a bypass switch.

From the fault tree diagram, the failure of the motor loads will only occur if all the rectifier module fails or all the inverter modules fail.

Reliability of System Configuration

The reliability of the system is calculated based on the configuration:

Considering the reliability of the rectifier modules arranged in series:

$$
R_{\text {rec } 1} \text { to } R_{\text {rec } 4}=R_{\text {rec } 1} \times R_{\text {rec } 2} \times R_{\text {rec } 3} \times R_{\text {rec } 4}=R_{\text {rec } 1,2,3,4} \cdots
$$

Assumption: let the reliability of the rectifier module be 0.85

Hence, $R_{\text {recl }, 2,3,4}=0.5435$

For reliability of the inverter $\left(R_{i n v}\right)$ module:

$$
R_{i V 1} \text { to } R_{i v 4}=R_{i V 1} \times R_{i V 2} \times R_{i V 3} \times R_{i V 4}=R_{i V n 1,2,3,4} \cdots
$$

Assumption: Let the reliability of all the Inverter module be 0.85

Hence, $R_{i V 1}$ to $R_{i v 4}=0.5435$

$$
\begin{aligned}
& R_{\text {systen }}=1-\left[\left(1-R_{\text {rec }, 1.4}\right) \times\left(1-R_{\text {inv1,4 }}\right)\right] \\
&=1-[(0.4565) \times(0.4565)] \\
&=0.7917 \\
& R_{\text {rec in parallel }}=1-\left[\left(1-R_{\text {rec } 1}\right) \times\left(1-R_{\text {rec } 2}\right) \times\left(1-R_{\text {rec } 3}\right) \times\left(1-R_{\text {rec } 4}\right)\right]
\end{aligned}
$$

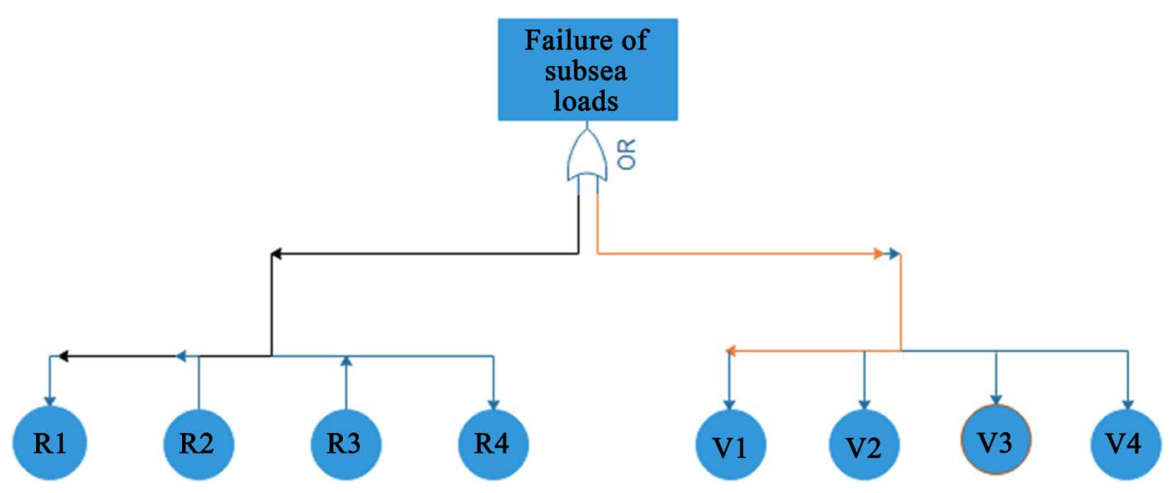

Figure 9. Fault tree diagram of the MSDC configuration. 
Therefore, the reliability of rectifier in parallel $\left(R_{\text {rec in parallel }}\right)$ is 0.9995 .

In a similar manner, the reliability of the inverter module in parallel is 0.9995 .

Considering the reliability of the system with its modules connected in parallel and the system connected in parallel as given in equation 2 is 0.99949 .

Figure 10 compares the value of the reliability of the system configuration modules arranged in series and in parallel.

From the Figure 10, R-series and R-Parallel represent the reliability of the system configuration for both series and parallel connection respectively without considering the subsea loads.

Considering subsea load modules for both series and parallel connection were compared, the reliability of series connection to the subsea loads is 0.5435 ; while that of parallel connection is 0.9995 . Figure 11 shows the comparison for both scenarios.

R-system is the reliability of the system configuration for all the motor loads to function as required. For our subsea loads to function at all time, without failure or loss time in production. From the reliability calculations, based on the assumed reliability for the rectifier and inverter modules, the failure rate of the motor loads is compensated by a bypass switch. For the adoption of the system configurations and also to reduce the complexity of subsea architecture, the series connection is preferred. Although the parallel connection has a higher reliability

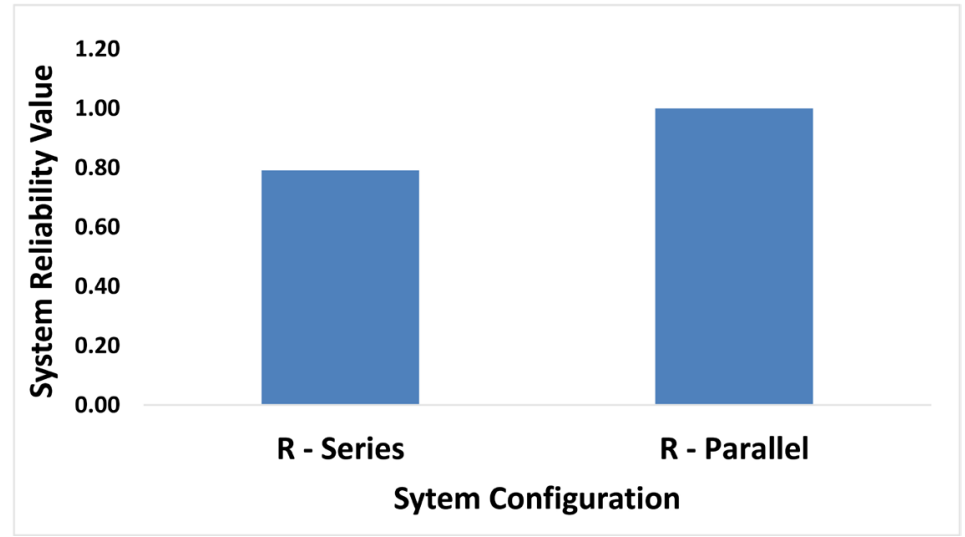

Figure 10. System reliability for series and parallel configuration.

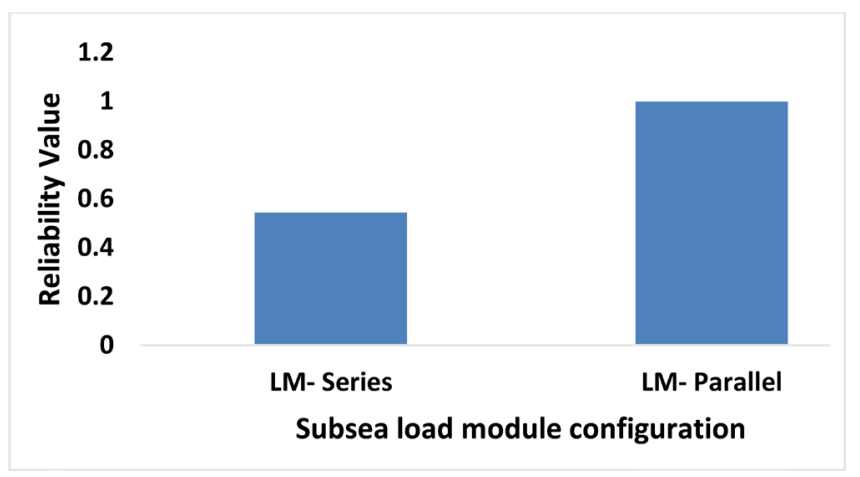

Figure 11. Reliability of subsea loads module configuration. 
than the series as shown in Figure 10 and Figure 11, the later is preferred if a bypass switch is provided but having a parallel will only increase cost and complexity of the architecture. This is because in series connection, the system works only when all components are in perfect condition, whereas in parallel systems, the system works as long as one component is in perfect condition [9]. From foregoing, it is obvious that procedures could be adopted in analyzing power generation for all electric subsea system, and it is recommended no risk item should be exempted not when conducting risk analysis to ascertain the system reliability.

\section{Conclusions}

This study analyses all electric subsea high power system for power generation and transmission in the offshore oil and gas industry for sustainable subsea development.

Data from Agbara and Akpo fields, all located in Nigeria were analysed using the MSDC model as an alternative power source for power generation and transmission to all subsea loads. To accomplish the analysis of power generation and transmission for subsea loads, the MAT lab SIMULINK software was employed to ascertain losses arising transmission of power to subsea systems.

The study demonstrates the feasibility of adopting high power systems to power subsea loads. This was proven and validated by the fact that the model runs successfully and all the values of voltage losses fall within the range as provided in National Electrical code: 210-19(a), (FPN 4) and 215-2(b) which recommends a 5 percent voltage drop for feeder circuit. Also, the reliability analysis shows it better to have series connection to subsea modular as long as bypass switch is provided.

\section{Acknowledgements}

The authors wish to express their gratitude to the University of Port Harcourt African Center of Excellence, Centre for Oil Field Chemical Research, Faculty of Engineering, University of Port Harcourt and Nigeria Maritime University for providing all the technical assistance required to conduct this study.

\section{Conflicts of Interest}

The authors declare no conflicts of interest regarding the publication of this paper.

\section{References}

[1] Lai, R., Zhang, D., Dong, D., Song, C., Todorovic, M.H., Gupta, R., Garces, L., Gunturi, S., Datta, R., Wijekoon, T. and Sihler, C. (2014) A Modular Subsea DC Electrical Power System. Offshore Technology Conference, Houston, Texas, USA, 5-8 May 2014. https://doi.org/10.4043/25263-MS

[2] Steiner, M., Micheal, A., Edward, T., Cornelia, N., Diego, A.B.B. and Stephen, L. (2013) Subsea Electrical Power Standardization, Paper No. PCIC Europe IS-50. 
[3] Oil and Gas Journal (2016) Joint Industry Project on Subsea Electric Power Standardization.

https://www.ogj.com/articles/2016/10/subsea-electric-power-standardization-seeksto-lower-development-costs.html

[4] Jorun, I.M., Eirik, V. and Magnus, K. (2012) Electrification of Offshore Petroleum Installation with Offshore Wind Integration. Renewable Energy, 50, 558-564. https://doi.org/10.1016/j.renene.2012.07.010

[5] Marcio, Y., Carlos, F.M.A., Bruno, A.A., Diego, C. and Mauricio, B.C.S. (2014) Integrated Subsea Production System: An Overview on Energy Distribution and Remote Control. IEEE Paper, PCIC BR 2014-24.

[6] Stephen, D.D. (1975) Power Testing of Offshore Generating Systems. Offshore Technology Conference OTC 2256, 136-138. https://doi.org/10.4043/2256-MS

[7] Wane, B., Angelucci, L., Tealdi, L., Ogujawa, J., Fasaanu, E., Adekanye, I., Afolabi, B. and Stanise, L. (2010) Mature filed Revitalisation: The Agbara Field Case History, Offshore Nigeria. SPE Annual Conference and Exhibition, Florence, 19-22 September 2010. https://doi.org/10.2118/135142-MS

[8] Ship-Technology (2018) Akpo Floating Storage and Offloading (FPSO) Vessel West Africa. https://www.ship-technology.com/projects/akpofpso/

[9] Mahmood Shaifiee (2014) Safety Risk and Reliability Offshore. Cranfield University Lecture Presentation.

\section{Nomenclature}

$\begin{array}{ll}\text { XLPE } & \text { Cross-Linked Polyethlene } \\ \text { HVDC } & \text { High Voltage Direct Current } \\ \text { GT } & \text { Gas Turbine } \\ \text { MW } & \text { Mega Watt } \\ \text { KV } & \text { Kilo Volt } \\ \text { OML } & \text { Oil Minning Licence } \\ \text { BOPD } & \text { Barrel of Oil Production per Day } \\ \text { KW } & \text { Kilo Watt } \\ \text { GT } & \text { Gas Turbine } \\ \text { MW } & \text { Mega Watt } \\ \text { MSDC } & \text { Modular Subsea Direct Current }\end{array}$

